\title{
Personal and Social Resources in Coping with Coronavirus Crisis Among Israeli-Palestinian Adults: Explanatory Study
}

\author{
Qutaiba Agbaria ${ }^{1}$ (D) Amnah Abu Mokh ${ }^{1}$
}

Accepted: 15 December 2020/Published online: 23 February 2021

(C) The Author(s), under exclusive licence to Springer Science+Business Media, LLC part of Springer Nature 2021

\begin{abstract}
The present study aims to explore the personal and social resources that Israeli-Palestinian adults use while coping with stress in response to the COVID-19 pandemic. The participant sample consisted of 985 Israeli-Palestinian adults, $58 \%$ of whom were females. Participants' ages ranged from 18 to 50 years old $(M=35.8, \mathrm{SD}=14.48)$, and they were recruited using a convenience sampling from the Israeli-Palestinian community living in Israel. Participants were asked to answer 16 questions about the coping resources they are adopting to deal with the coronavirus crisis. The findings of the study indicate that social and family support, self-control skills, self-efficacy, religious level, optimism, and subjective well-being are the most common resources the participants have to cope with the coronavirus crisis. These findings align with previous studies across the globe on the importance of these personal and social resources for coping with stressful events.
\end{abstract}

Keywords Coping with coronavirus crisis $\cdot$ Personal resources $\cdot$ Social resources $\cdot$ IsraeliPalestinian adults

The recent outbreak of coronavirus disease (COVID-19) across the globe gave rise to an increasing amount of information and concerns about the various ways people are coping with this pandemic. Global media, local and international health organizations (including World Health Organization), epidemiologists, virologists, and decision-makers are disseminating information, recommendations, and minute-by-minute updates on the number of people infected with COVID-19 and the number of deaths as a result of this infection. Physicians, doctors, and experts around the world are rushing to develop medicines and vaccines that can help reduce the spread of the virus, but they have not had any success yet.

The present study investigates the social and personal resources that people use while coping with stress in response to the COVID-19 pandemic. Previous studies on similar

Qutaiba Agbaria

qutaiba100psych@yahoo.com 
stressful circumstances found that such crises have negative psychological outcomes such as depression, anxiety, stress, and other psychopathological symptoms (Agbaria et al. 2012; Lu et al. 2012). Coping with stressful events was studied in different contexts, and several models were proposed to examine the coping strategies that people used in these circumstances. The main concern of the present study is examining the personal and social resources IsraeliPalestinian adults seek to cope with the coronavirus crisis.

\section{Theoretical background}

\section{Coping with Stress due to COVID-19 Outbreak}

The current coronavirus pandemic first appeared in December 2019 in China and quickly spread to most countries in the world. Up to this moment, the world is still facing the rapid spread of the virus without success in finding effective medication or vaccination. As a result, most countries have taken procedures to slow down the outbreak by imposing social restrictions on people and businesses. These restrictions, however, have negative psychological effects on people who are self-isolating, social distancing, and/or quarantined. In Israel, the first confirmed coronavirus case was discovered by the end of January, and now there are more than 16,000 patients diagnosed with the disease, with more than 220 deaths and more than 100,000 people in self-isolation.

Similar to most countries across the globe, the Israeli government imposed limits to people's movement, work, and recreational activities and required that all education facilities switch to distance learning. Since then, more than 1 million people lost their jobs. The rapid spread of COVID-19 virus and the increasing number of deaths globally, combined with the mass quarantine and social distancing measures adopted by many governments, have significantly increased stress and anxiety among people from all affected countries. Moreover, the increasing attention given to the horrors of this pandemic across all media platforms and the high consumption of COVID-19 related news and media has further intensified feelings of uncertainty. This has ultimately magnified the levels of stress, anxiety, and tension felt by people under quarantine. Therefore, this current pandemic is perceived by many people as a highly stressful event.

Scholars perceive that COVID-19 quarantine periods may escalate already existing mental health conditions, such as PTSD, anger, irritability, avoidance behavior, emotional disturbance and exhaustion, low mood, depression, insomnia, fear, stress, tension, and anxiety, and/or lead to new ones (Brooks et al. 2020). One reason for this is the limited face-to-face (offline) contact between people which is thought to increase levels of depression and feelings of helplessness and alienation among quarantined individuals (Pancani et al. 2020). Moreover, social restrictions during quarantine also pose a significant constraint to individuals' satisfaction of basic psychological needs such as autonomy, competence, and relatedness (Cantarero et al. 2020) Additionally, quarantine periods also cause individuals to feel more lonely, bored, and frustrated (Buheji et al. 2020). This has led many scholars and practitioners to look for alternative ways for individuals to cope with the stress, anxiety, and other mental health problems intensified during this period.

\section{Coping with Stress}

Coping with stress is "the multi-dimensional process that refers to the ways in which people deal with stress" (Thompson et al. 1992, p. 434). Moreover, according to Lazarus and 
Folkman's (1984) appraisal theory, the primary appraisal is to recognize if a threat exists and whether it is irrelevant, benign-positive, or stressful, while the second appraisal is to evaluate if it is controllable or not and to choose appropriate coping strategies to deal with it. Therefore, coping implies efforts inputted into managing stress (Holroyd and Lazarus 1982).

Furthermore, Krohne (1986) identified several characteristics of coping. He defined coping as a process that includes both behavioral and cognitive acts that aim to remove the imbalance between one's capacities and the demands that are taxing or even exceeding his/her capacities. Krohne's idea was well reflected in Lazarus and Folkman's (1984) definition of coping to which was referred to as "constantly changing cognitive and behavioral efforts to manage specific external and/or internal demands that are appraised as taxing or exceeding the resources of the person" (p. 141). This definition implies that coping needs effort and is part of the secondary appraisal, where appraisal of the person's coping resources is involved. They further proposed two forms of coping: emotion-focused coping and problem-focused coping.

When the appraisal of the situation is that it is impossible to change the environment to reduce stress, people are more likely to choose emotion-focused coping strategies in order to regulate their emotional response to the problem (Lazarus and Folkman 1984). Lazarus and Lazarus (1991) argued that emotions play a central role in our lives. By regulating their emotions through avoidance, distancing, denial, or looking on the bright side of things, individuals are able to reduce the level of experienced stress (Healy and McKay 2000). Some forms of emotion-focused coping focus on changing the way the situation or problem is constructed without changing the reality. This can be perceived as reappraisal of the stressor. Notice that by changing the cognitive appraisal of the threat (e.g., it is not as important as I thought), an individual can successfully cope with stress. Other emotion-focused coping strategies, such as selective attention and avoidance, may not involve changing the cognitive appraisal of the situation. Instead, they may lead to certain changes in behavior, e.g., engaging in recreational activities or indulge in drinking and smoking to get one's mind off stressful events.

On the other hand, problem-focused coping strategies aim at solving the problem directly through processes like defining the problem, finding alternative ways, evaluating the consequences, selecting, and then acting. Therefore, problem-focused coping strategies are more preferred when situations are appraised to be able to change. Problem-focused coping strategies, such as cognitive and motivational changes, can be directed at the environment as well as the self as means to reappraise the situation. Nezu and Perri (1989) identified five stages in this process, namely, problem orientation, problem definition and formulation, generation of alternative solutions, decision-making, and solution implementation and verification.

\section{Personal and Social Resources in Coping with Stress}

Resources are often referred to as "available means." Therefore, the term "resource" can be used to name something that constitutes a mean for executing a goal (Hobfoll 2004; Lazarus 1966). Resources are defined as items, personal conditions, and forms of energy that are either of themselves value for survival or used as means to achieve objectives possessing that value (Hobfoll 2004). Hence, they allow individuals to avoid unnecessary stressors and to improve their process of coping with stress (Davydov et al. 2010; Steinhardt and Dolbier 2008; Tugade et al. 2004). Personal and social resources are specific properties that a person might take advantage of in a dangerous situation or for maintaining optimal conditions (Friborg et al. 2003; Hjemdal et al. 2006). This holds true for members of the Israeli-Palestinian community 
living in Israel who demonstrate the positive effects of these resources for coping with stressful situations (Agbaria 2013; Agbaria 2019; Agbaria and Bdier 2019; Agbaria and Natur 2018; Agbaria et al. 2012, 2017). Following from this, I will highlight the personal and social resources and strategies Israeli-Palestinian individuals make use of for coping with stress, namely, social support, self-control, self- efficacy, religiosity, optimism, and subjective wellbeing.

\section{Social Support}

Social support consists of resources provided upon interacting with other people, groups, and larger communities (Lin et al. 1979). These are members of family, friends, and neighbors or members of the local community and other social groups who are available at times when a given unit requires psychological, physical, or financial support. Raina and others (Raina et al. 2004) divide social support into formal resources - such as the support of a professional - and non-formal resources such as support from spouse, family members, friends, and co-workers. Pritzker and Minter (2014) emphasize that social support functions like a safety net that mitigates the effects of disadvantageous life events and traumas. Research shows that social support in difficult situations, for instance, when facing stress or a crisis which results in social maladjustment or exclusion, acts in an immunizing manner (Langeland and Wahl 2009; Nausheen et al. 2009). Therefore, social support allows one to actively cope with stress, activate skills of assertive behavior, and increase their tendency to take advantage of a task-based style (Shen 2009).

Social support given to women with breast cancer is a key reference point in effective stress management (Ozdemir and Tas Arslan 2018). Family members, friends, and neighbors had satisfactory coping skills to work in harmony in adverse circumstances (Das et al. 2017). Moreover, moderation analyses revealed that social support moderated the relationship between perceived stress and ability to cope with stress (Rodriguez et al. 2019). It has also been shown that nursing students' stress coping levels are affected by social support and self-esteem (Y1ldırım et al. 2017). In line with these studies, and with the general characteristics of the Israel-Palestinian community as a collective society, we can hypothesize that social support is a significant resource that Israel-Palestinian individuals use for coping with stress due to coronavirus outbreak.

\section{Self-Control}

Self-control reflects one's ability to delay or abstain from an immediately rewarding behavior in favor of a behavior that is consistent with one's long-term goals (Thoresen and Mahoney 1974). Rosenbaum (1998) describes self-control as a system of goal-oriented cognitive skills that enable people to achieve their objectives, manage negative thoughts and emotions, delay gratification and cope with stressful situations. A large body of research has shown that perceptions of self-control are associated with a variety of positive outcomes such as better physical and mental health, psychological well-being, and lower mortality rates (Bandura 1997; Eizenman et al. 1997). Greater self-control abilities are also associated with lower reactivity to stressors in everyday life (Agbaria 2019; Agbaria and Bdier 2019; Neupert et al. 2007a, b; Ong et al. 2005). Self-control decisions can enhance the impact of immediately rewarding attributes and reducing the efficacy of regions promoting behaviors that are consistent with long-term goals (Maier et al. 2015). Self-control also correlated with lower perceived stress, but higher physiological biomarkers of stress (Brock 2016). 


\section{Self-Efficacy}

Self-efficacy has been defined as the extent to which an individual believes he or she has the ability to organize and perform the behaviors needed for achieving personal/professional goals (Bandura 1977). This perceived self-efficacy centers around individuals' beliefs in their capabilities to exercise control over their own functioning and over events that affect their lives (Bandura 2010). Evidence from this review of 22 articles showed that high self-efficacy was associated with low symptom occurrence and symptom distress and higher general health. High self-efficacy thus predicted physical and emotional well-being. Low self-efficacy, on the other hand, was associated with higher severity in symptoms, poorer outcomes, and lower overall functioning (White et al. 2019). Self-efficacy globally had a negative significant correlation with stress (White et al. 2019). It showed that the index of health stress affected QOL mainly through perceived stress, and that self-efficacy affected QOL by reducing perceived stress and increasing QOL (Kreitler et al. 2007). Teacher stress and teacher selfefficacy are consistently shown to be negatively related and to predict adults' cognitive, emotional, and behavioral responses differently. More specifically, teachers' high levels of stress correlate negatively with teachers' job satisfaction and job commitment, but positively with burnout and teacher attrition. Whereas teacher self-efficacy correlates positively with teacher job satisfaction and job commitment, but negatively with burnout and teacher attrition (Skaalvik and Skaalvik 2017a, b).

\section{Religiosity}

Religiosity has been associated with greater psychological functioning, physical health, and perceived significance of one's life (Abu-Raiya and Pargament 2011; Hood et al. 2009; Koenig et al. 2001; Paloutzian and Park 2005), as well as increased overall well-being (Al-Issa 2000; Koenig et al. 1999; Witter et al. 1985) and self-esteem (Falbo and Shepperd 1986). Research has shown that among cancer patients in Malaysia, more spiritual respondents reported higher levels of quality of life and lower levels of stress (Sharif and Ong 2019). Seeking the support of God had a strong correlation with reduced psychological distress (Agbaria 2013; Agbaria and Natur 2018; Nouman and Benyamini 2019). On another study, religiousness was only indirectly negatively related to the stress constructs. Non-religiosity linked to all stress constructs (Abu-Hilal et al. 2017). High religiousness has also been shown to play a buffering role among older Somalis as exposure to severe war trauma was not associated with high levels of PTSD or somatization among the religious respondents (Mölsä et al. 2017).

\section{Optimism}

Optimism is a mental attitude that reflects a belief or hope that the outcome of specific endeavors, or outcomes in general, will be positive, favorable, and desirable. This is usually referred to in psychology as dispositional optimism. It thus reflects a belief that future conditions will work out for the best (Weiten and Lloyd 2005). For this reason, optimism is seen as a trait that fosters resilience in the face of stress (Bates 2015).

Theories of optimism include dispositional models and models of explanatory style. Methods to measure optimism have been developed within theoretical systems such as the various forms of the Life Orientation Test for the original definition of optimism and the Attributional Style Questionnaire designed to test optimism in terms of explanatory style 
(Abramson et al. 1978). Optimism and coping with stress were found to be strongly correlated, as hierarchical regression analyses revealed that the interaction between them predicted a large proportion of the variance in both perceived stress and life satisfaction (Reed 2016). Optimism has psychological benefits for acute stressors as well as chronic stressors (Baumgartner et al. 2018). Optimism was associated with heightened SBP and DBP stress reactivity and lower daily cortisol output (Puig-Perez et al. 2017). In another study, there was a positive relationship between the dependent variable "perceived life stress" and the cognitive predictor variables 'self-efficacy, optimism, self-esteem, positive affect, and negative affect' (Higgins 2017).

\section{Subjective Well-Being}

Subjective well-being (SWB) refers both to people's subjective assessment of the quality of their lives, happiness, and satisfaction as well as to the qualitative assessment of their inner experiences in various domains (Diener 2009). SWB is based on the individual's emotional reactions and cognitive judgments that provide a comprehensive perspective of mood and self-evaluations of satisfaction/ happiness both in general terms and with respect to specific aspects of life. SWB were the most important correlates of the level of PTG among participants (Rzeszutek et al. 2019). Positive psychological states - such as resilience, forgiveness, quality of life, and psychological wellbeing - are more preferred than negative psychological states, especially during stressful situations (Aziz 2017). Good levels of psychological well-being correlate positively with the ability to develop more adaptive strategies to deal with stress (Gustems-Carnicer et al. 2019). Different patterns of appraisals and coping predict each component of spiritual well-being and that all three components - particularly those of meaning and peace - are related to psychological adjustment (Park 2017). Five dimensions of coping resources (physical, cognitive, emotional, social, and spiritual) demonstrate a protective effect on the relationship between cumulative, traumatic, and stressful life experiences and well-being among older adults in prison (Maschi et al. 2015).

Following from this, the present study explores the personal and social resources that Arab Israeli-Palestinian adults living in Israel make use of to cope with stress due to the COVID-19 outbreak. The Arab society in Israel live in a collective society that is experiencing rapid modernization along with "Israelization" on one hand (Al-Hajj 1996) while also experiencing movements in the opposite direction by Islamization and "Palestinianization" (Smooha 2004). Moreover, the Arab Israeli-Palestinian community has captured itself as a society on the fringes of Israeli society in terms of social and health services, along with a low economic status and low mental health welfare compared with the Jewish community living in Israel. During the coronavirus crisis, the Arab Israeli-Palestinian community was further marginalized in the public discourse as it does not meet the "priority criteria" in governmental health services. Therefore, this community has been excluded from the general mass COVID-19 tests and the public guidelines around the disease. Therefore, the question of what support sources Arab Israeli-Palestinians have is significant in the shadow of these conditions.

\section{Method}

\section{Sample}

The sample consisted of 985 Israeli-Palestinian adults, 58\% of whom were females. Participants' ages ranged from 18 to 50 years old $(M=35.8, \mathrm{SD}=14.48)$, and they were chosen in a 
convenience sampling from Arab Israeli-Palestinian community living in Israel. A total of $81.24 \%$ of the participants were Muslims, $10.25 \%$ were Christians, and the remainder were Druze. A total of $44.45 \%$ of the participants have obtained high school degrees, $28.34 \%$ of the participants have obtained graduate degrees (BA), and $9.45 \%$ have obtained postgraduate degrees (MA and $\mathrm{PhD}$ ), while the remainder spent less than 12 years in school. More than $22 \%$ of the participants had low socio-economic status, $55 \%$ were of middle socio-economic status, and the remainder were of high socio-economic status. A total of $57 \%$ of the participants were from villages (rural), and the remainder were from cities (urban). A total of $63.55 \%$ of the participants were married, $26.75 \%$ were bachelors, and the remainder were divorced or widowed.

\section{Measures}

Demographic variables questionnaire This instrument was created by the researchers and included self-reported questions of gender, age, socio-economic status, academic degree, residence, and religion.

Coping resources questionnaire This scale was built by the researchers. It includes 16 questions about their coping resources while dealing with the coronavirus crisis, with a scale of $1=$ "strongly disagree" and 10="strongly agree." The scale was tested by five Arab professional experts in psychology, counseling, Arabic language, and education. They evaluated both the clarity and relevance of the questions. Translation was done by the researchers and with the help of professional experts. All the items were with a load level greater than 0.4.

\section{Research Procedure}

The study sample was recruited through convenience sampling at six colleges in Israel. The research was conducted in 2020 and lasted 2 months. After obtaining the needed clearances from the ethical committee, the questionnaires were distributed using the Internet (Google Forms) along with forms explaining the study's purpose and making sure that the respondents are aware that questionnaires will remain anonymous.

\section{Statistical Analysis}

Means, standard deviations, and maximum and minimum values for research variables were calculated first and percent for all the questions.

\section{Results}

In order to answer the research question, the distributions of the demographic variables were calculated, and then the means and standard deviations of coping resources were calculated according to the various demographic variables (Table 1).

Table 1 demonstrated that religiosity and faith level, optimism, family and social support, self-efficacy, self-control skills, body efficacy, and positive emotions got high percentages, more than 7. However, the other questions got less percentages. 
Table 1 Percentage of answers to the study questions ( $\mathrm{n}=985)$

\begin{tabular}{|c|c|c|c|c|c|c|c|c|c|c|c|}
\hline & 1 & 2 & 3 & 4 & 5 & 6 & 7 & 8 & 9 & 10 & $\begin{array}{l}\text { Cumulative } \\
\text { percentage } \\
(7-10)\end{array}$ \\
\hline $\begin{array}{c}\text { Religiosity } \\
\text { and faith } \\
\text { level }\end{array}$ & $2.7 \%$ & $0.7 \%$ & $0.3 \%$ & $1.4 \%$ & $2.7 \%$ & $1.7 \%$ & $4.7 \%$ & $8.8 \%$ & $11.8 \%$ & $65.2 \%$ & $90.5 \%$ \\
\hline $\begin{array}{l}\text { Self-control } \\
\text { skills }\end{array}$ & $0 \%$ & $0 \%$ & $0 \%$ & $2 \%$ & $1.7 \%$ & $8.1 \%$ & $10.1 \%$ & $23.6 \%$ & $16.9 \%$ & $37.5 \%$ & $88.1 \%$ \\
\hline Optimism & $2.4 \%$ & $0 \%$ & $1 \%$ & $1.7 \%$ & $2.4 \%$ & $6.1 \%$ & $6.4 \%$ & $15.5 \%$ & $19.6 \%$ & $44.9 \%$ & $86.4 \%$ \\
\hline $\begin{array}{l}\text { Perceived } \\
\text { social } \\
\text { support }\end{array}$ & $1.7 \%$ & $1.4 \%$ & $2.4 \%$ & $1.7 \%$ & $4.4 \%$ & $6.1 \%$ & $8.4 \%$ & $16.6 \%$ & $16.6 \%$ & $40.9 \%$ & $82.5 \%$ \\
\hline $\begin{array}{l}\text { Familial and } \\
\text { social } \\
\text { support }\end{array}$ & $3.7 \%$ & $1.4 \%$ & $2.7 \%$ & $4.7 \%$ & $3.2 \%$ & $4.7 \%$ & $21.6 \%$ & $18.2 \%$ & $18.5 \%$ & $18.6 \%$ & $76.9 \%$ \\
\hline Body efficacy & $2.4 \%$ & $1.7 \%$ & $2.7 \%$ & $4.7 \%$ & $9.8 \%$ & $4.5 \%$ & $14.2 \%$ & $17.2 \%$ & $19.8 \%$ & $23 \%$ & $74.2 \%$ \\
\hline Self-efficacy & $6.8 \%$ & $2.4 \%$ & $4.1 \%$ & $4.7 \%$ & $6.2 \%$ & $4.9 \%$ & $17.6 \%$ & $13.2 \%$ & $16.1 \%$ & $24.2 \%$ & $71.1 \%$ \\
\hline $\begin{array}{l}\text { Positive } \\
\text { emotions } \\
\text { and } \\
\text { happiness }\end{array}$ & $7.8 \%$ & $2.7 \%$ & $6.4 \%$ & $7.8 \%$ & $15.9 \%$ & $10.8 \%$ & $14.2 \%$ & $16.2 \%$ & $8.8 \%$ & $9.5 \%$ & $48.7 \%$ \\
\hline $\begin{array}{l}\text { Moral support } \\
\text { from clerics }\end{array}$ & $10.1 \%$ & $4.1 \%$ & $7.1 \%$ & $7.1 \%$ & $13.2 \%$ & $12.2 \%$ & $15.9 \%$ & $13.2 \%$ & $7.4 \%$ & $9.8 \%$ & $46.3 \%$ \\
\hline $\begin{array}{l}\text { Moral support } \\
\text { from } \\
\text { specialists } \\
\text { in the field }\end{array}$ & $7.1 \%$ & $3.4 \%$ & $15.7 \%$ & $14.4 \%$ & $9.5 \%$ & $8.1 \%$ & $12.8 \%$ & $14.2 \%$ & $9.1 \%$ & $5.7 \%$ & $41.8 \%$ \\
\hline $\begin{array}{l}\text { Good } \\
\text { economic } \\
\text { status }\end{array}$ & $12.2 \%$ & $3.7 \%$ & $5.7 \%$ & $15.4 \%$ & $11.8 \%$ & $10.5 \%$ & $13.5 \%$ & $9.1 \%$ & $8.4 \%$ & $9.6 \%$ & $40.6 \%$ \\
\hline $\begin{array}{l}\text { Confidence in } \\
\text { the ability } \\
\text { of the state } \\
\text { to provide } \\
\text { security } \\
\text { and health } \\
\text { services }\end{array}$ & $12.5 \%$ & $5.1 \%$ & $8.4 \%$ & $6.4 \%$ & $15.5 \%$ & $12.8 \%$ & $14.5 \%$ & $11.8 \%$ & $3.4 \%$ & $9.5 \%$ & $39.2 \%$ \\
\hline $\begin{array}{l}\text { Moral support } \\
\text { from } \\
\text { intellectuals }\end{array}$ & $15.5 \%$ & $7.1 \%$ & $9.5 \%$ & $9.1 \%$ & $12.8 \%$ & $14.2 \%$ & $9.1 \%$ & $9.8 \%$ & $3.4 \%$ & $9.5 \%$ & $31.8 \%$ \\
\hline $\begin{array}{l}\text { Moral support } \\
\text { from social } \\
\text { network }\end{array}$ & $16.9 \%$ & $6.8 \%$ & $10.8 \%$ & $8.8 \%$ & $11.1 \%$ & $14.5 \%$ & $9.5 \%$ & $9.1 \%$ & $3.7 \%$ & $8.8 \%$ & $31.1 \%$ \\
\hline $\begin{array}{l}\text { Moral support } \\
\text { from the } \\
\text { media }\end{array}$ & $26 \%$ & $8.1 \%$ & $11.8 \%$ & $7.4 \%$ & $15.5 \%$ & $11.1 \%$ & $8.4 \%$ & $5.4 \%$ & $1 \%$ & $5.1 \%$ & $19.9 \%$ \\
\hline $\begin{array}{l}\text { Moral support } \\
\text { from } \\
\text { politicians }\end{array}$ & & & & & & & & & & & \\
\hline
\end{tabular}

Table 2 shows other descriptive statistics calculated in order to expand our understanding of the sample results.

Table 2 show also that religiosity and faith level, optimism, familial and social support, selfefficacy, self-control skills, and positive emotions get the high means in comparison with the other questions. 
Table 2 Descriptive statistics for the study questions ( $n=985)$

\begin{tabular}{|c|c|c|c|c|c|}
\hline & Mean & $\begin{array}{l}\text { Standard } \\
\text { deviation }\end{array}$ & Median & Minimum & Maximum \\
\hline Religiosity and faith level & 8.95 & 2.01 & 10 & 1 & 10 \\
\hline Optimism & 8.55 & 1.97 & 9 & 1 & 10 \\
\hline Self-control skills & 8.52 & 1.51 & 9 & 4 & 10 \\
\hline Familial and social support & 8.26 & 2.15 & 9 & 1 & 10 \\
\hline Body efficacy & 7.43 & 2.35 & 8 & 1 & 10 \\
\hline Self-efficacy & 7.37 & 2.48 & 7 & 1 & 10 \\
\hline positive emotions and happiness & 7.23 & 2.29 & 7.5 & 1 & 10 \\
\hline Moral support from clerics & 6.46 & 2.82 & 7 & 1 & 10 \\
\hline Moral support from specialists in the field & 6.19 & 2.97 & 7 & 1 & 10 \\
\hline Good economic status & 6.10 & 2.55 & 6 & 1 & 10 \\
\hline $\begin{array}{l}\text { Confidence in the ability of the state to provide security } \\
\text { and health services }\end{array}$ & 5.88 & 2.67 & 6 & 1 & 10 \\
\hline Moral support from intellectuals & 5.49 & 2.70 & 6 & 1 & 10 \\
\hline Moral support from social network & 5.11 & 2.81 & 5 & 1 & 10 \\
\hline Moral support from the media & 5.01 & 2.82 & 5 & 1 & 10 \\
\hline Moral support from politicians & 4.14 & 2.66 & 4 & 1 & 10 \\
\hline
\end{tabular}

\section{Discussion}

The aim of the current research is to examine the personal and social support sources that are used by people in the Arab Israeli-Palestinian community to cope with the present coronavirus outbreak. The findings of this research demonstrate similar results to the global research on the importance of social and family support, mental resilience, self-control skills, self-efficacy, religious affiliation, optimism, and mental well-being as common resources that help individuals cope with everyday stress, especially during times of crisis such as the COVID-19 pandemic.

In terms of personal resources, the results show that religiosity as a coping source is perceived as the highest value among Arab Israeli-Palestinian adults. These findings align with previous studies which emphasize the importance of religiosity and faith as protective factors that contribute to more resilience and greater ability to cope with stressful events (AbuHilal et al. 2017; Agbaria 2019; Agbaria and Bdier 2019; Agbaria et al. 2017; Agbaria and Natur 2018; Nouman and Benyamini 2019).

These findings can be explained that religiosity may protect against stressful behaviors. As reflected by Agbaria and Wattad's study (2011), participants use sentences like "in the end, God will help me" and "acceptance and patience during crises will grant me more heavenly rewards." Agbaria and Wattad (2011) also had numerous Muslim participants describe verses from the Quran or words from the prophet Muhammad that may be relevant to coping with crises. Thus, persons with high religiosity may have different cognitions based on their religious values that inform their behavior in a manner that discourages against maladaptive behaviors in stressful conditions.

The results also show that optimism as a coping source is perceived high among Arab Israeli-Palestinian adults. These findings align with previous studies that emphasize the importance of optimism as a protective factor that contributes to more resilience and greater ability to cope with stressful events (Baumgartner et al. 2018; Higgins 2017; Puig-Perez et al. 2017).

Optimists' believe that they can actively cope with threats (Carver and Scheier 2014; Carver et al. 2010). Moreover, optimism is closely related to self-efficacy (Scholz et al. 
2002). Pavlova and Silbereisen's (2013) study on the impact of optimism in occupational uncertainty found that optimism predicted an increase in approach strategies only under favorable conditions in the labor market. What these studies inform is that optimists are also better at tailoring their coping responses to available opportunities. While demonstrating the close relationship between coping ability and optimism, these studies have argued that optimistic individuals change their coping strategy depending on the situation (i.e., whenever it is controllable). Therefore, coping ability and optimism were seen to be strongly correlated. They were also both individually strong predictors of perceived stress and life satisfaction, agreeing with findings from previous research (Chang 1998; Kato 2012; Ng et al. 2014).

Additionally, the results show that subjective well-being as a coping source is perceived high among Arab Israeli-Palestinian adults. These findings align with previous studies that emphasize the importance of subjective well-being as a protective factor that contributes to more resilience and greater ability to cope with stressful events (Agbaria 2019; Agbaria and Bdier 2019; Agbaria et al. 2017; Agbaria and Natur 2018; Rzeszutek et al. 2019).

People with positive subjective well-being (SWB) respond to negative events faster and therefore cope with them better than people with low levels of subjective well-being (Diener and Diener 1996). The study's findings show a correlation between positive SWB and social adjustment, in line with an earlier study that found that people with high levels of SWB had more satisfying relationships and were more capable of becoming attached to others and to help, understand, and cooperate with them. People with high levels of SWB also act in an altruistic manner, resolve conflicts efficiently, feel more in control of their lives, cope effectively with stressful situations, and set tangible goals in life (Lyubomirsky et al. 2005).

Another coping source that is perceived high among Arab Israeli-Palestinian adults is family and social support. These findings align with previous studies that emphasize the importance of family and social support as a protective factor that contributes to more resilience and greater ability to cope with stressful events (Agbaria 2019; Agbaria and Bdier 2019; Agbaria et al. 2017; Agbaria and Natur 2018; Rodriguez et al. 2019; Yildırım et al. 2017).

Family support and social support are thus protective factors that contribute to the development of people, improving not only social and personal adjustment but also the ability to cope with stressful situations. Each social support system makes a unique contribution to each individual's coping abilities. For instance, good relations with one's parents contribute to a sense of satisfaction and increased subjective well-being, which may be used as a measure of personal adjustment. Also, people who build a network of social connections with other peers function better socially and cope better with stress than people who suffer from a lack of social support (Wentzel et al. 2004). A sense of closeness and connection can thus provide protection against becoming overwhelmed by stressful situations.

Furthermore, self-efficacy as a coping source is also perceived high among Arab IsraeliPalestinian adults These findings align with previous studies that not only the importance of self-efficacy as a protective factor that contributes to more resilience and greater ability to cope with stressful events (Hampton and Newcomb 2018; Skaalvik and Skaalvik 2017a, b; White et al. 2019).

People with high self-efficacy generally believe that they are in control of their own lives, perceiving that their actions and decisions shape the outcomes of their lives. Choices affecting health, such as smoking, physical exercise, dieting, condom use, dental hygiene, seat belt use, and breast self-examination, have all been associated with high self-efficacy (Conner and Norman 2005). Self-efficacy may also reflect beliefs relate to goals, such as whether health 
behavior change will be initiated, how much effort will be expended, and how long the behavior change will be sustained in the face of obstacles and failures. Self-efficacy thus influences how people set health goals (e.g., "I intend to reduce my bad habits" or "I intend to quit risky behaviors") and how effectively they follow through with these intentions.

Last but not least, self-control as a coping source is perceived high among Arab IsraeliPalestinian adults These findings align with previous studies that emphasize the importance of self-control skills as a protective factor that contributes to more resilience and greater ability to cope with stressful events (Agbaria 2019; Agbaria and Bdier 2019; Agbaria et al. 2017; Agbaria and Natur 2018; Agbaria et al. 2012; Neupert et al. 2007a, b; Ong et al. 2005).

A possible explanation of this result can be found in the way self-control skills are implemented. People with these skills are able to divert attention and think creatively to find alternative solutions, change automatic ways of thinking and replace them with planned and more appropriate ones, and use self-talk to resist difficult and stressful situations and to resist temptation. Self-control skills can thus lead to a more balanced thinking and therefore more planned and orderly responses instead of exaggerated worry, bothersome thoughts, and selfcriticism. Hence, self-control skills enable individuals to cope effectively with new stressful situations.

\section{Limitations, Future directions, and Conclusions}

The current study was novel in a number of ways but had several limitations. First, participants were recruited as a non-random convenience sample rather than as a randomized subset of the population of interest. Further, all participants were from one ethnic group, which may limit generalization. However, the homogeneity of the current sample was intentional in order to provide specific insights into the individual characteristics that may be particularly important for seeking personal and social resources among this unique sample of Arab Israeli-Palestinian adults. Nevertheless, data was provided through self-report questionnaires that may be confounded by reporting bias. Thus, future research may consider integrating other sources of information. Finally, the chosen self-resources based on one question and not to full scale. Future research should replicate the current findings according to answers to professional scales that tested these resources. Future research can also consider other variables that may correlate with the use of these resources such as demographic variables to build more complicated analysis.

In summary, the findings indicate that people tend to use personal and social resources to cope with the Coronavirus crisis. The results clearly indicate that the level religiosity and faith, family and social support, self-efficacy, self-control, and mental well-being are perceived as significant resources that are helping individuals cope with the current circumstances. These resources are particularly high when compared with other resources captured as significant (moral support from clerics, intellectuals, politicians, social networks, media, economic security, as well as confidence in the state's ability to cope with this crisis).

These findings are consistent with hundreds of studies in literature that have been conducted around the world over the last few decades. Such studies indicate the importance of personal, social, and spiritual resources as elements of people's resilience and ability to cope with the various life struggles. These findings are also consistent with previous literature from Western cultures regarding the contribution of these variables in reducing stress. Thus, these variables are important in Western and non-Western societies as well. This is especially true 
with respect to the current population of Arab Israeli-Palestinians who live in a unique, dualistic society. Despite the unique social, political, and ethnic characteristics of Arab Israeli-Palestinian culture, these resources appear to contribute to psychological well-being and improved social functioning in a similar manner as other people from around the globe. This provides support for the universal significance of these variables. In conclusion, these findings may inform intervention programs, such as psychoeducation-based efforts, that may facilitate the development of these resources among Israeli-Palestinian adults in order to improve their abilities to cope with stressful conditions in general and with the coronavirus crisis in particular.

\section{Declarations}

Conflict of Interest The manuscript has only been submitted to The International journalof mental health and addiction, it will not be submitted elsewhere while under consideration, and it hasnot been published elsewhere either in similar form or verbatim. I amresponsible for the reported research and all authors have participated in the concept and design;analysis and interpretation of data; drafting or revising of the manuscript, and I have reviewed/approvedthe manuscript. There are no conflicts of interest.

Informed Consent Informed consent was obtained from allindividual participants included in the study.

Ethical Approval All procedures performed in studies involvinghuman participants were in accordance with the ethicalstandards of the institutional and/or national research committee (include nameof committee + referencenumber) and with the 1964 Helsinki declaration and its later amendments or comparable ethicalstandards.

\section{References}

Abramson, L. Y., Seligman, M. E., \& Teasdale, J. D. (1978). Learned helplessness in humans: Critique and reformulation. Journal of Abnormal Psychology, 87(1), 49. https://doi.org/10.1037/0021-843X.87.1.49.

Abu-Hilal, M., Al-Bahrani, M., \& Al-Zedjali, M. (2017). Can religiosity boost meaning in life and suppress stress for Muslim college students? Mental Health, Religion and Culture, 20(3), 203-216. https://doi.org/10.1080/ 13674676.2017.1324835.

Abu-Raiya, H., \& Pargament, K. I. (2011). Putting research into practice: Toward a clinical psychology of religion and spirituality. Pastoral psychology and psychology of religion in. dialogue, 13-27.

Agbaria, Q. (2013). Depression among Arab students in Israel: The contribution of religiosity, happiness, social support and self-control. Sociology Study, 3(10), 721-738.

Agbaria, Q. (2019). Predictors of personal and social adjustment among Israeli-Palestinian teenagers. Child Indicators Research, 1-17. https://doi.org/10.1037/0022-0663.96.2.195.

Agbaria, Q., \& Bdier, D. (2019). The role of self-control, social support and (positive and negative affects) in reducing test anxiety among Arab teenagers in Israel. Child Indicators Research, 1-19. https://doi.org/10. 1007/s12187-019-09669-9.

Agbaria, Q., Mahamid, F., \& Ziya Berte, D. (2017). Social support, self-control, religiousness and engagement in high risk-behaviors among adolescents. The International Journal of Indian Psychology, 4, 13-33.

Agbaria, Q., \& Natur, N. (2018). The relationship between violence in the family and adolescents aggression: The mediator role of self-control, social support, religiosity, and well-being. Children and Youth Services Review, 91, 447-456. https://doi.org/10.1016/j.childyouth.2018.06.016.

Agbaria, Q., Ronen, T., \& Hamama, L. (2012). The link between developmental components (age and gender), need to belong and resources of self-control and feelings of happiness, and frequency of symptoms among Arab adolescents in Israel. Children and Youth Services Review, 34(10), 2018-2027. https://doi.org/10.1016/ j.childyouth.2012.03.009.

Agbaria, Q., \& Wattad, N. (2011). Self-control and religiosity as related to subjective well-being among Arab students. In third International conference Opening Gates in Teacher Education (pp. 25-26).

Al-Hajj, M. A. (1996). Identity and orientation among the Arabs in Israel. State, Government and International Relations, Haifa University. 
Al-Issa, I. E. (2000). Al-Junūn: Mental illness in the Islamic world. Inc: International Universities Press.

Aziz, I. A. (2017). Individual difference predictors of well-being among displaced persons who live under stressful conditions (Doctoral dissertation, University of Leicester).

Bandura, A. (1977). Self-efficacy: Toward a unifying theory of behavioral change. Psychological Review, 84(2), 191-215. https://doi.org/10.1037/0033-295X.84.2.191.

Bandura, A. (1997). Self-efficacy and health behaviour. Cambridge handbook of psychology, health and medicine, 160-162.

Bandura, A. (2010). Self-efficacy. The Corsini encyclopedia of psychology, 1-3. https://doi.org/10.1002/ 9780470479216. corpsy0836.

Bates, R. H. (2015). When things fell apart. Cambridge University Press.

Baumgartner, J. N., Schneider, T. R., \& Capiola, A. (2018). Investigating the relationship between optimism and stress responses: A biopsychosocial perspective. Personality and Individual Differences, 129, 114-118. https://doi.org/10.1016/j.paid.2018.03.021.

Brock, C. I. (2016). The relationship between self-regulation and stress, sleep, and behavioral health. https:// scholarship.claremont.edu/cmc theses $/ 1370$

Brooks, S. K., Webster, R. K., Smith, L. E., Woodland, L., Wessely, S., Greenberg, N., \& Gideon, R. J. (2020). The psychological impact of quarantine and how to reduce it: rapid review of the evidence. Lancet, 395 , 912-920.

Buheji, M., Jahrami, H., \& Dhah, A. (2020). Minimising stress exposure during pandemics similar to COVID19. International Journal of Psychology and Behavioral Sciences, 10(1), 9-16.

Cantarero, K., van Tilburg, W. A., \& Smoktunowicz, E. (2020). Affirming basic psychological needs promotes mental well-being during the COVID-19 outbreak. Retrieved from: https://oi.org/10.31234/osf.io/pyhce.

Carver, C. S., \& Scheier, M. F. (2014). Dispositional optimism. Trends in Cognitive Sciences, 18(6), $293-299$. https://doi.org/10.1016/j.tics.2014.02.003.

Carver, C. S., Scheier, M. F., \& Segerstrom, S. C. (2010). Optimism. Clinical Psychology Review, 30(7), 879889. https://doi.org/10.1016/j.cpr.2010.01.006.

Chang, E. C. (1998). Dispositional optimism and primary and secondary appraisal of a stressor: Controlling for confounding influences and relations to coping and psychological and physical adjustment. Journal of Personality and Social Psychology, 74(4), 1109.

Conner, M., \& Norman, P. (2005). Predicting health behaviour. McGraw-Hill Education (UK).

Das, S., Das, B., Nath, K., Dutta, A., Bora, P., \& Hazarika, M. (2017). Impact of stress, coping, social support, and resilience of families having children with autism: A North East India-based study. Asian Journal of Psychiatry, 28, 133-139. https://doi.org/10.1016/j.ajp.2017.03.040.

Davydov, D. M., Stewart, R., Ritchie, K., \& Chaudieu, I. (2010). Resilience and mental health. Clinical Psychology Review, 30(5), 479-495. https://doi.org/10.1016/j.cpr.2010.03.003.

Diener, E. (2009). Subjective well-being. In In The science of well-being (pp. 11-58). Dordrecht: Springer. https://doi.org/10.1007/978-90-481-2350-6_2.

Diener, E., \& Diener, C. (1996). Most people are happy. Psychological Science, 7(3), 181-185. https://doi.org/ 10.1111/j.1467-9280.1996.tb00354.x.

Eizenman, D. R., Nesselroade, J. R., Featherman, D. L., \& Rowe, J. W. (1997). Intraindividual variability in perceived control in an older sample: The MacArthur successful aging studies. Psychology and Aging, 12(3), 489.

Falbo, T., \& Shepperd, J. A. (1986). Self-righteousness: Cognitive, power, and religious characteristics. Journal of Research in Personality, 20(2), 145-157. https://doi.org/10.1016/0092-6566(86)90114-5.

Friborg, O., Hjemdal, O., Rosenvinge, J. H., \& Martinussen, M. (2003). A new rating scale for adult resilience: what are the central protective resources behind healthy adjustment? International Journal of Methods in Psychiatric Research, 12(2), 65-76. https://doi.org/10.1002/mpr.143.

Gustems-Carnicer, J., Calderon, C., Batalla-Flores, A., \& Esteban-Bara, F. (2019). Role of coping responses in the relationship between perceived stress and psychological well-being in a sample of Spanish educational teacher students. Psychological Reports, 122(2), 380-397. https://doi.org/10.1177/0033294118758904.

Hampton, M. M., \& Newcomb, P. (2018). Self-efficacy and stress among informal caregivers of individuals at end of life. Journal of Hospice \& Palliative Nursing, 20(5), 471-477. https://doi.org/10.1097/NJH. 0000000000000464 .

Healy, C. M., \& McKay, M. F. (2000). Nursing stress: the effects of coping strategies and job satisfaction in a sample of Australian nurses. Journal of Advanced Nursing, 31(3), 681-688. https://doi.org/10.1046/j.13652648.2000.01323.x.

Higgins, G. (2017). The role of cognition in stress: Relationship between perceived life stress, self-efficacy, optimism, self-esteem, positive affect, negative affect, and work stress (Doctoral dissertation, Dublin, National College of Ireland). http://trap.ncirl.ie/id/eprint/2819 
Hjemdal, O., Friborg, O., Stiles, T. C., Rosenvinge, J. H., \& Martinussen, M. (2006). Resilience predicting psychiatric symptoms: A prospective study of protective factors and their role in adjustment to stressful life events. Clinical Psychology \& Psychotherapy: An International Journal of Theory \& Practice, 13(3), 194 201. https://doi.org/10.1002/cpp.488.

Hobfoll, S. E. (2004). Stress, culture, and community: The psychology and philosophy of stress. Springer Science \& Business Media.

Holroyd, K. A., \& Lazarus, R. S. (1982). Stress, coping and somatic adaptation. Handbook of stress: Theoretical and clinical aspects, 21-35.

Hood, R. W., Hill, P. C., \& Spilka, B. (2009). The psychology of religion: An empirical approach. New York. NY: Guilford.

Kato, T. (2012). Development of the coping flexibility scale: Evidence for the coping flexibility hypothesis. Journal of Counseling Psychology, 59(2), 262. https://doi.org/10.1037/a0027770.

Koenig, H. G., Idler, E., Kasl, S., Hays, J. C., George, L. K., Musick, M., ... \& Benson, H. (1999). Religion, spirituality, and medicine: a rebuttal to skeptics. https://doi.org/10.2190/C2FB-95VW-FKYD-C8RV

Koenig, H. G., McCullough, M. E., \& Larson, D. B. (2001). Religion and health. New York, NY: Oxford University Press Inc, 1, 276-291.

Kreitler, S., Peleg, D., \& Ehrenfeld, M. (2007). Stress, self-efficacy and quality of life in cancer patients. PsychoOncology: Journal of the Psychological, Social and Behavioral Dimensions of Cancer, 16(4), 329-341. https://doi.org/10.1002/pon.1063.

Krohne, H. W. (1986). Coping with stress. In Dynamics of stress (pp. 207-232). Boston: Springer. https://doi. org/10.1007/978-1-4684-5122-1 11.

Langeland, E., \& Wahl, A. K. (2009). The impact of social support on mental health service users' sense of coherence: A longitudinal panel survey. International Journal of Nursing Studies, 46(6), 830-837. https:// doi.org/10.1016/j.ijnurstu.2008.12.017.

Lazarus, R. S. (1966). Psychological stress and the coping process.

Lazarus, R. S., \& Folkman, S. (1984). Stress, appraisal, and coping. New York: Springer Publishing Company.

Lazarus, R. S., \& Lazarus, R. S. (1991). Emotion and adaptation. Oxford University Press on Demand.

Lin, N., Ensel, W. M., Simeone, R. S., \& Kuo, W. (1979). Social support, stressful life events, and illness: A model and an empirical test. Journal of Health and Social Behavior, 108-119 https://www.jstor.org/stable/ 2136433.

Lu, Y., Nyunt, M. S. Z., Gwee, X., Feng, L., Feng, L., Kua, E. H., et al. (2012). Life event stress and chronic obstructive pulmonary disease (COPD): associations with mental well-being and quality of life in a population-based study. BMJ Open, 2(6), e001674. https://doi.org/10.1136/bmjopen-2012-001674.

Lyubomirsky, S., Sheldon, K. M., \& Schkade, D. (2005). Pursuing happiness: The architecture of sustainable change. Review of General Psychology, 9(2), 111-131. https://doi.org/10.1037/1089-2680.9.2.111.

Maier, S. U., Makwana, A. B., \& Hare, T. A. (2015). Acute stress impairs self-control in goal-directed choice by altering multiple functional connections within the brain's decision circuits. Neuron, 87(3), 621-631. https:// doi.org/10.1016/j.neuron.2015.07.005.

Maschi, T., Viola, D., Morgen, K., \& Koskinen, L. (2015). Trauma, stress, grief, loss, and separation among older adults in prison: The protective role of coping resources on physical and mental well-being. Journal of Crime and Justice, 38(1), 113-136. https://doi.org/10.1080/0735648X.2013.808853.

Mölsä, M., Kuittinen, S., Tiilikainen, M., Honkasalo, M. L., \& Punamäki, R. L. (2017). Mental health among older refugees: the role of trauma, discrimination, and religiousness. Aging \& Mental Health, 21(8), 829837. https://doi.org/10.1080/13607863.2016.1165183.

Nausheen, B., Gidron, Y., Peveler, R., \& Moss-Morris, R. (2009). Social support and cancer progression: a systematic review. Journal of Psychosomatic Research, 67(5), 403-415.

Neupert, S. D., Almeida, D. M., \& Charles, S. T. (2007a). Age differences in reactivity to daily stressors: The role of personal control. The Journals of Gerontology Series B: Psychological Sciences and Social Sciences, 62(4), P216-P225. https://doi.org/10.1093/geronb/62.4.P216.

Neupert, S. D., Almeida, D. M., \& Charles, S. T. (2007b). Age differences in reactivity to daily stressors: The role of personal control. The Journals of Gerontology Series B: Psychological Sciences and Social Sciences, 62(4), P216-P225. https://doi.org/10.1093/geronb/62.4.P216.

Nezu, A. M., \& Perri, M. G. (1989). Social problem-solving therapy for unipolar depression: an initial dismantling investigation. Journal of Consulting and Clinical Psychology, 57(3), 408. https://doi.org/10. 1037/0022-006X.57.3.408.

Ng, H. K., Cheung, R. Y. H., \& Tam, K. P. (2014). Unraveling the link between narcissism and psychological health: New evidence from coping flexibility. Personality and Individual Differences, 70, 7-10. https:/doi. org/10.1016/j.paid.2014.06.006. 
Nouman, H., \& Benyamini, Y. (2019). Religious women's coping with infertility: Do culturally adapted religious coping strategies contribute to well-being and health? International Journal of Behavioral Medicine, 26(2), 154-164. https://doi.org/10.1007/s12529-018-9757-5.

Ong, A. D., Bergeman, C. S., \& Bisconti, T. L. (2005). Unique effects of daily perceived control on anxiety symptomatology during conjugal bereavement. Personality and Individual Differences, 38(5), 1057-1067. https://doi.org/10.1016/j.paid.2004.07.004.

Ozdemir, D., \& Tas Arslan, F. (2018). An investigation of the relationship between social support and coping with stress in women with breast cancer. Psycho-oncology, 27(9), 2214-2219. https://doi.org/10.1002/pon. 4798.

Paloutzian, R. F., \& Park, C. L. (2005). Integrative themes in the current science of the psychology of religion. Handbook of the psychology of religion and spirituality, 1, 3-20.

Pancani, L., Marinucci, M., Aureli, N., \& Riva, P. (2020). Forced social isolation and mental health: A study on 1006 Italians under COVID-19 quarantine. Retrieved from: https://oi.org/10.31234/osf.io/uacfj

Park, C. L. (2017). Spiritual well-being after trauma: Correlates with appraisals, coping, and psychological adjustment. Journal of Prevention \& Intervention in the Community, 45(4), 297-307. https://doi.org/10. 1080/10852352.2016.1197752.

Pavlova, M. K., \& Silbereisen, R. K. (2013). Dispositional optimism fosters opportunity-congruent coping with occupational uncertainty. Journal of Personality, 81(1), 76-86. https://doi.org/10.1111/j.1467-6494.2012. 00782.x.

Pritzker, S., \& Minter, A. (2014). Measuring adolescent resilience: An examination of the cross-ethnic validity of the RS-14. Children and Youth Services Review, 44, 328-333. https://doi.org/10.1016/j.childyouth.2014.06. 022.

Puig-Perez, S., Hackett, R. A., Salvador, A., \& Steptoe, A. (2017). Optimism moderates psychophysiological responses to stress in older people with Type 2 diabetes. Psychophysiology, 54(4), 536-543. https://doi.org/ 10.1111/psyp. 12806 .

Raina, P., O’Donnell, M., Schwellnus, H., Rosenbaum, P., King, G., Brehaut, J., et al. (2004). Caregiving process and caregiver burden: conceptual models to guide research and practice. BMC Pediatrics, 4(1), 1. https://doi.org/10.1186/1471-2431-4-1.

Reed, D. J. (2016). Coping with occupational stress: the role of optimism and coping flexibility. Psychology Research and Behavior Management, 9, 71. https://doi.org/10.2147/PRBM.S97595.

Rodriguez, L., Groarke, A., \& Dolan, P. (2019). Individual predictors of adolescent adjustment to maternal cancer: The role of perceived stress, coping, social support, attachment, and self-efficacy. Cancer Reports, 2(2), e1145. https://doi.org/10.1002/cnr2.1145.

Rosenbaum, M. (1998). Opening versus closing strategies in controlling one's responses to experience. In Personal control in action (pp. 61-84). Boston: Springer. https://doi.org/10.1007/978-1-4757-2901-6_3.

Rzeszutek, M., Oniszczenko, W., \& Gruszczyńska, E. (2019). Satisfaction with life, Big-Five personality traits and posttraumatic growth among people living with HIV. Journal of Happiness Studies, 20(1), 35-50. https://doi.org/10.1007/s10902-017-9925-3.

Scholz, U., Doña, B. G., Sud, S., \& Schwarzer, R. (2002). Is general self-efficacy a universal construct? Psychometric findings from 25 countries. European Journal of Psychological Assessment, 18(3), 242. https://doi.org/10.1027//1015-5759.18.3.242.

Sharif, S. P., \& Ong, F. S. (2019). Education moderates the relationship between spirituality with quality of life and stress among Malay Muslim women with breast cancer. Journal of Religion and Health, 58(4), 10601071. https://doi.org/10.1007/s10943-018-0587-1.

Shen, Y. E. (2009). Relationships between self-efficacy, social support and stress coping strategies in Chinese primary and secondary school teachers. Stress and Health: Journal of the International Society for the Investigation of Stress, 25(2), 129-138. https://doi.org/10.1002/smi.1229.

Skaalvik, E. M., \& Skaalvik, S. (2017a). Motivated for teaching? Associations with school goal structure, teacher self-efficacy, job satisfaction and emotional exhaustion. Teaching and Teacher Education, 67, 152-160. https://doi.org/10.1016/j.tate.2017.06.006.

Skaalvik, E. M., \& Skaalvik, S. (2017b). Still motivated to teach? A study of school context variables, stress and job satisfaction among teachers in senior high school. Social Psychology of Education, 20(1), 15-37. https:// doi.org/10.1007/s11218-016-9363-9.

Smooha, S. (2004). Index of Arab-Jewish Relations in Israel. Haifa: The Jewish-Arab Center, University of Haifa.

Steinhardt, M., \& Dolbier, C. (2008). Evaluation of a resilience intervention to enhance coping strategies and protective factors and decrease symptomatology. Journal of American College Health, 56(4), 445-453. https://doi.org/10.3200/JACH.56.44.445-454. 
Thompson, R. J., Gil, K. M., Abrams, M. R., \& Phillips, G. (1992). Stress, coping, and psychological adjustment of adults with sickle cell disease. Journal of Consulting and Clinical Psychology, 60(3), 433. https://doi.org/ 10.1037/0022-006X.60.3.433.

Thoresen, C. E., \& Mahoney, M. J. (1974). Behavioral self-control. New York: Holt, Rinehart and Winston.

Tugade, M. M., Fredrickson, B. L., \& Feldman Barrett, L. (2004). Psychological resilience and positive emotional granularity: Examining the benefits of positive emotions on coping and health. Journal of Personality, 72(6), 1161-1190. https://doi.org/10.1111/j.1467-6494.2004.00294.x.

Weiten, W., \& Lloyd, M. (2005). Psychology applied to modern life. Belmont: Wadsworth.

Wentzel, K. R., Barry, C. M., \& Caldwell, K. A. (2004). Friendships in middle school: Influences on motivation and school adjustment. Journal of Educational Psychology, 96(2), 195. https://doi.org/10.1037/0022-0663. 96.2.195.

White, L. L., Cohen, M. Z., Berger, A. M., Kupzyk, K. A., \& Bierman, P. J. (2019, January). Self-efficacy for management of symptoms and symptom distress in adults with cancer: An integrative review. Oncology Nursing Forum, 46(1).

Witter, R. A., Stock, W. A., Okun, M. A., \& Haring, M. J. (1985). Religion and subjective well-being in adulthood: A quantitative synthesis. Review of Religious Research, 332-342 https://www.jstor.org/stable/ 3511048.

Yıldırım, N., Karaca, A., Cangur, S., Acıkgoz, F., \& Akkus, D. (2017). The relationship between educational stress, stress coping, self-esteem, social support, and health status among nursing students in Turkey: A structural equation modeling approach. Nurse Education Today, 48, 33-39. https://doi.org/10.1016/j.nedt. 2016.09.014.

Publisher's Note Springer Nature remains neutral with regard to jurisdictional claims in published maps and institutional affiliations. 